\title{
Cooperation Between the Countries Around Lake Chad Basin: An Assessment
}

\author{
Safiya Wada $\mathrm{Abu}^{1}$, Adam Okene Ahmed ${ }^{2}$ \\ ${ }^{1}$ Research Fellow, Department of History \& War Studies, Nigerian Defence Academy, Africa's Top Military \\ University, PMB 2109, Kaduna, Nigeria \\ 2 Professor, Security History, Conflict Resolution \& International Studies, Directorate of Linkages \& \\ Collaboration, Nigeria Defence Academy, PMB 2109 Kaduna, Nigeria \\ Correspondence: Safiya Wada Abu, Research Fellow, Department of History \& War Studies, Nigerian Defence \\ Academy, Africa's Top Military University, PMB 2109, Kaduna, Nigeria. E-mail: safiyawadaabu@gmail.com
}

Received: August 27, 2021

Accepted: September 13, 2021

Online Published: November 29, 2021

doi:10.5539/ass.v17n12p1

URL: https://doi.org/10.5539/ass.v17n12p1

\begin{abstract}
The Lake Chad Basin is an important natural resource that cut across several countries among which are Nigeria, Niger, Chad, Cameroon, Algeria, Central African Republic and Libya. In a bid to ensure the effective utilization of the water of the basin, the countries have engaged in cooperation through the creation of Lake Chad Basin Commission. The Commission has embarked on certain programmes to achieve its aim, hence the need for the assessment of the cooperation between countries around the basin. This work is an assessment albeit critical, of the cooperation within that commission. Part of the findings of the paper is that the Lake Chad Basin Commission has been unable to achieve objectives it sets for itself. Certain challenges which include but not limited to, lack of political will among members of the Commission, reoccurrence of violence, lack of adequate finance, poor organizational structure, cultural and language difference have worked either individually or in tandem to frustrate the realization of what appeared ab initio to be the noble and lofty goals of the commission. The contention of the paper therefore, is that the Lake Chad Basin Commission member states should reflect and modernize its initial objectives and operationalize the ingredients of its cooperation to derive the positivity laden in the agreements or else risk the extinction of an important water resource. Data for the paper were sourced using both primary and secondary. Other variables and methodological approaches like analysis, discourse, and accountability and of course, chronological delineations were generously employed in reconstruction. Study of this nature is multidisciplinary and knitted in the International studies, Security studies, and Diplomatic and Military history.
\end{abstract}

Keywords: Lake Chad Basin, criminality, violence banditry, security, natural resources, commission, cooperation, regional integration and regional good governance

\section{Introduction}

The Lake Chad Basin is a body of fresh water found in the West African region of Africa; the $4^{\text {th }}$ largest in Africa and the $12^{\text {th }}$ largest in the world. The lake has over the years been reducing in size and quantity. This has significant impact on the economies of states surrounding the lake. Due to these impacts of the shrinking of the lake on the countries' economies and the livelihood of their citizen, a Commission was set up by these states to ensure the continued existence of the lake. This was the Lake Chad Basin Commission.

The Lake Chad Basin Commission is an intergovernmental organization created by states around the Lake Chad Basin; Nigeria, Niger, Chad, Cameroon, Algeria, Central African Republic and Libya. The Commission was established in 1964 to ensure the effective, efficient utilization and management of the water and its resources to ensure the security of their member states citizens. However, the Lake Chad Basin is still experiencing inconsistency due to the climatic condition and non- climatic features, the effect of this, on the available resources in the Lake Chad Basin, economies of the riparian states and the wider community far away from the lake is severe. It is to this, that the paper will attempt to assess the Lake Chad Basin Commission as a body of intergovernmental organization aimed at the effective management of the water and the resources of the Lake Chad Basin area. This paper is interested in the extent to which the Commission has achieved its agreed objectives and the prospects. 


\section{Literature Review}

The Lake Chad area has always been attractive to researchers and writers of diverse disciplinary callings. A cursory peep into the existing literatures reveals this assertion. Unoha (2012) assesses the regional implication of Boko haram that started as a home grown terror group with activities subsequently spilling to other countries in the Lake Chad region. He argues that the group's ability to assess resources of the region almost unhindered poses a serious threat to West African sub-region. To the author, Nigeria's inability to curtail the spread of the menace of terrorism and criminality as the forerunner in ensuring peace and security in Africa and West Africa sub region has reinforced and mitigated security concordance. He concludes, that only when there is combined efforts by regional and other international security architectures aimed at cutting the group's ability to access resources will the threat be put to an end.

Eric O, Oyebande, L. and Oguntola, J. (2006), work is a report on the Lake Chad Basin and the series of challenges that the lake and those who benefit from its resources face. Their report further assesses the various mechanisms that have been put in place by both nations having access to the lake's resources and other international body seeking to ensure the preservation of the lake and its resources. Providing different possible analysis and gamut that could be put in place to facilitate the achievements of a sustainable Lake Chad Basin, the writers underscore the urgent need for concerted efforts to improve security and suave administration in the region. Ibahim Umara (2020) traces the emergence of LCBC to not only the strategic location of the Lake Chad but also the determination of the leaders of the country. He added that the socio-cultural, political and historical affinities among the states surrounding the Lake Chad have facilitated the emergence of the commission. Using the functionalist perspective to explain the reason for the cooperation among States and the challenges encountered by commission, Umara contends that each State in the Commission is involved to pursue socioeconomic national interest. Umara brings to the fore a connecting nexus between development, environment and security, especially among the LCBC member states in the pursuit of these vested interests. He states that, the LCBC has been successful in some aspects of its responsibilities in the lake area. Although, the security challenges faced by the member countries have necessitated the expansion of the role of the commission in the area of security, the author argues that the real and deep positivity and fruits of the cooperation can only be accessed and assessed in few years from now.

Expounding on the regionalization of security of the Lake Chad area, Umara and Tar (2020), assess the nature of conflict caused by the Boko Haram terror group and how it has added to the regionalization of insecurity, terror and criminality. This necessitated the LCBC member and non-member states responsibility in counter-terrorism and counter-insurgency operations to expand the mandates and security architecture the Multinational Joint Task Force (MNJTF). Though the regional efforts put together by member states of LCBC and African Union (AU) under the authorization of the United Nations, the LCBC is seen to have reinvigorated the MNJTF due Boko Haram activities. To Umara and Tar, the expansion of the mandate of the MNJTF was also necessitated by the Multidimensional Complexity of Nigerian relations with the Republic of Chad which has been determined by Chad colonial master France, the need to achieve regional stability through peaceful co-existence despite the sub-experience of bastardization of borders. In the same vein, the case over the maritime and land dispute between Nigeria and Cameroon over the Bakassi Penninsula, influenced also by colonial master, France have created some quite discomfort between the two nation. Hence, the reinvigoration of the MNJTF to contain the transnational reach of the group became necessary in order to bring together states with diverse interests but with a common objective of bringing an end to the conflict within the region.

Agreeing to the reason for the relative success of the LCBC, the report of the Federal Ministry for Economic Cooperation and Development earlier on contended that, the LCBC is one of the regional institutions enjoying the collaboration of all its member states in settling disputes that revolve around States borders (Federal Ministry for Economic Cooperation and Development, 2015). The report which is a study on the effect of climate change on the Sahel region of Africa was narrowed down to the Lake Chad Basin. The report further looked at certain factors that have contributed to the continued disappearance of the Lake thereby creating damaging consequences on the otherwise extensive land for pasture, farming and fish stock to the countries of Chad, Cameroon, Niger, Nigeria, Central Africa Republic and Libya. The study's contribution lies in its further projection of the future effects and challenges of climate change in an effort to aid the development of strategies to ameliorate its effects on the Lake and its beneficiary (Federal Ministry for Economic Cooperation and Development, 2015). 


\section{Definition of Concepts}

\subsection{Cooperation}

Cooperation among states have been going on for decades. This is because no state is an island and self-sufficient despite relating in an anarchical international system. The need to therefore relate with one another becomes imperative (Paulo, 2014). As a result, cooperation is when actors adjust their behaviors to the actual or anticipated preferences of others (Milner, 1992). This implies that states make decisions putting the interest of other states into consideration to prevent the negative consequences as a result of those decisions. Cooperation as a result is the coming together of states to achieve those objectives or goals that would otherwise be impossible to achieve unilaterally. With regards to the Lake Chad Basin area, cooperation is the coming together of states around the Lake Chad Basin to collectively ensure the continued existence of the lake and its shared resources.

\subsection{Security}

Security is the state of being secured or free from danger and risk. It is a situation where either an individual, social group or geo-political entity is protected against any form of danger, espionage or attack of any sort, internally or externally (Okene, 2011). Also, it is an absence to those tendencies which could undermine internal cohesion and corporate existence of the state and its ability to maintain its vital institutions for the promotion of its core values and socio-political and economic objectives, as well as meet the legitimate aspirations of the people (Imobighe, 1990).

Furthermore, security could also easily be discussed in conjunction with threat to, and doctrine of, security. While threat to security refers to any act that has the potential of undermining the peace, stability, positive coexistence and progress of the state thereby constituting obstacles to the political and material aggregation, doctrine of security is the articulation of the fundamental principles that governs the management of security which normally flow from the states' ideology or philosophy of public affairs (Ahmed, 2008). The individuals mandated by law to ensure security are Security Operatives while the style, modems, models and methodology they used is generally termed Operations. Regional and national securities are core to this study as countries of the Basin are determined to maintain socio- political stability and security devoid of terrorism and banditry

\subsection{Integration}

On its own, Integration is the satisfaction of the various components of a social polity with regard to justice, fair play, equitable distribution of resources and ability to access the accruing national opportunities. It is the progressive lessening of ethnic, cultural and regional tensions and discontinuities in the process of creating a homogenous political community (Bienen, 1983). It is further conceptualizes as the socio-psycho paradigm that involves the creation of a very high level of mental and physical comprehensiveness (Binder, 1964). In the same vein, integration could be applied separately and in group to either geo-polity like territory, nationality, or socio-psychological imperatives like value system, social behavior and group category like elite and mass. In this realm therefore, integration could manifest among social beings living in a region, geo-political entity and should necessarily lead to trust, communal harmony, aggregation of material development and common constructive political objective(s).

However, a mega conception of integration provides areas of clarification that integration works. These include:

a. the fusion of norms and cultures;

b. promotion of economic interdependence;

c. the narrowing of gap between the elite and the masses, the urban and the rural areas, rich and poor;

d. equitable resolution of emergent crises and conflicts;

e. the sharing of mutual experiences so that people can discover that they have undergone some important experiences together (Mazrui, 1972).

Generally speaking therefore, integration is the feeling of the history of togetherness and high sense of community in all sectors. In a way integration is development in all ramifications of human and physical endeavors. The final objective of integration is that society is lived, guided, guarded and administered with tolerable minimum conflicts, in such a way that it benefits all. In this research, integration should be ultimate expectation of the countries living around the Lake Chad if not physically but in terms of economy, monetary, currencies and trade and merchandise.

\section{Geography and History of the Lake Chad Basin}

The Lake Chad Basin is a body of fresh water cutting across several states (Onuha, 2015). It is found between 
latitude $6^{0}$ and $24^{0}$ to the North and longitude $7^{0}$ and $24^{\circ}$ to the east, covering an estimated $8 \%$ of Africa total land surface area between Algeria, Chad, Niger, Cameroon, Libya, Nigeria, Central Africa Republic and Sudan (Fortman \& Oguntola, 2016). The Lake Chad Basin is surrounded to the north by the Ahagger Mountains in Algeria, the border descends southwards towards the Tibesti Highlands that forms the border between Libya and Sudan. The Southern borders are defined by the Mongos hills in CAR and the Adamawa mountains at about $6^{0} \mathrm{~N}$ all the way to the west by the Mandaras in Northern Cameroon $10^{\circ} \mathrm{N}$. The Jos plateau marks the western boundary in the Nigerian sector of the Basin (De Young, Antonia, Sinead, \& Sandy, 2012). The Lake Basin receives 85 percent of its water from River Chari in the southern part and the remaining 15 percent is received from river Logone and Kamadougou Yobe river from the north-west (Onuha, 2015).

The Lake Chad is the $12^{\text {th }}$ largest lake in the world and the $4^{\text {th }}$ largest in Africa, after Lake Victoria, Lake Tanganyika, and Lake Nyasa (Fortune Afafrica, 2017). The lake has been experiencing series of changes to its size over the years from its original size 5000 years of $1,000,000 \mathrm{~km}^{2}(390,000 \mathrm{sq}$. $\mathrm{mm}$ ) to a fragment of that size. Over the last forty years, the size has continued to shrink from $25000 \mathrm{~km}^{2}$ to $2500 \mathrm{~km}^{2}$ and around 2015 to about $8000 \mathrm{~km}$ (Lake Chad Basin Commission). This shrinking of the Lake to fraction of its original size has made the Lake to be referred to in some cycles as a "disappearing Lake (World Food Program, 2016).

The Lake Chad according to Food Agricultural Organization (FAO), is a unique Lake that is not found in any other part of the world due to its deposition of fresh water in a hot, dried with little rainfall zone. The climate of the Lake Chad Basin area which also determines the level of both rainfall and the degree of evaporation, is divided into six with a monsoonal rainfall (Odada, Lekan, \& Oguntola, 2005). It is as result that the continued shrinkage of the lake has been partly attributed to the climate (Hansel, 2017). Rainfall in the lake area is low to the level of evaporation from it. The climatic condition does not only affect the lake but also that of the countries around it. The impact of this climatic condition therefore, is seen not only in the reduced size of the lake, the amount of inflow to the lake from the countries around it but also the border towns' socio-economic activities of the countries around the lake. These negative impact affects not only the riparian states but also those not in direct contact with the lake (De Young, Antonia, Sinead, \& Sandy, 2012). A strong factor to the shrinking of the Lake, apart from the reduced inflow to it is the consistent increase in the population around it.

\section{Peopling and Population around the Lake Chad Basin Area}

The population of Lake Chad region is diverse, with an estimate of 70 ethnic groups. The official language of the basin countries are either English or French, a reflection of the respective colonizers of the countries: British (Nigeria) and French (Chad, Niger, and Cameroon). However, most people in the Lake Chad Basin are uneducated, hence speaks several local dialects instead of their official languages. The languages spoken in the region are Kanuri (Niger and Nigeria); Fulfude (Niger, Nigeria, and Cameroon), and Chadian Arabic (Chad). Most people speak Hausa, a popular language in Northern Nigeria. Mixing of races, blurring of tribal roles, the interactions between different tribes and their cultures as well as religions have increased social interactions among the different ethnic groups in the basin areas for centuries. This multiculturalism and pluralism in terms of cultures, languages and religions has contributed to the survival and the flourishing of the zone in the past (Ogbozor, 2016). For example, the Kanuri language spoken by majority dates back to the Kanem Bornu Empire, The Wadai, Bighirmi and the Peul Empire of Sokoto, reflects the historical linkage of the people before the coming of the colonial master (Odada, Lekan, \& Oguntola, 2005).

The Lake Chad Basin population is one of the fastest growing in the world. The population has been increasing from 11.7million since 1990, 22million in the 1991 census, 37million in 2004 by UNEP report and about 50million in 2015 (Lake Chad Basin Commission). This population is majorly made up of people from the four riparian states of Niger, Chad, Cameroon and Nigeria that are up to 39million having direct access to the Lake, with Nigerians making up about 60percents of these riparian town's populations (De Young, Antonia, Sinead, \& Sandy, 2012).

The people around the Lake are usually involved in different activities to ensure their livelihood, through the effective utilization of the Lake itself, its banks and islands. These activities include agricultural activities such as; cotton, groundnut, millet sorghum, cowpea, rice, onions and vegetables farming that have gone on for ages. Other activities in the area include, Mining, especially gold mining, exploration and the exploitation of oil, fishing in dam, rivers, floodplains and the Lake, manufacturing of cotton, ginning leather works, milling and food production, rearing of animals (De Young, Antonia, Sinead, \& Sandy, 2012). Despite this, fishing is the most predominant activity that a larger portion of the population engages in, accounting for over 45 percent of the Lake internally generated revenue. According to Ovie and Emma, fish gotten from the lake annually is estimated at about 150000 tones that worth over US\$54million, leading to the creation of a nodal market that 
gained both local popularity and international status (De Young, Antonia, Sinead, \& Sandy, 2012).

\section{Problems of the Lake Chad Basin Area}

Certain factors have been challenging the continued existence of the Lake Chad Basin. These factors include the climate and population of the area. The climate is hot and dry with obvious significant negative impact on the lake. First, climate determines the amount of rainfall and evaporation of an area. The hot climatic condition of the Lake Chad Basin area has resulted to the reduced amount of rainfall received in and around the basin area. This affects the quantity of water that flows into the river from it sources in the countries around the lake. In addition, this reduced quantity of the lake water resulted to the growth of some unwanted plants, encouraging the death and migration of fish species, causing reduced yield of fish for the population around the Lake Chad Basin area. Also, the prolonged absence of rain in the lake area from 1970, resulted in majority of the lake population losing their source of livelihood. These populations include mostly, the settlements of Niger, Chad and Cameroon around the lake whose major source of livelihood is the exploration and exploitation of the Lakes resources (Odada, Lekan, \& Oguntola, 2005).

The population around the Lake Chad Basin poses serious threat to the existence of the lake. The population of the Lake Chad Basin has been on the increase. The increase in the population implies the increasing need and dependence on the Lake and its resources in an area with insufficient rainfall and flow from its other sources. Hence, the shrinking of the Lake Chad along with the continued usage of the water by the population, whose need increases along with their numbers and the lack of adequate rainfall into the lake to make up for the used water (Onuha, 2015). This situation was witnessed right from the drought of the 1960's (Odada, Lekan, \& Oguntola, 2005).

\section{Background to the Lake Chad Basin Commission}

With the realization of its importance, the need to collectively provide solution to the continuous shrinking of the Lake Chad Basin due to the climatic condition and the prolonged period of drought on the economic activities of population of countries around the Lake Chad in order to ensure its continue existence as well as its catchment area became imperative ( Living Waters Programme). The Lake Chad Basin and its catchment area provide a viable source of living an estimated 50million people living in the border towns of the countries around it for centuries (De Young, Antonia, Sinead, \& Sandy, 2012 ). The depletion of its resources by increasing number of the population and settlements has been reducing the available resources and threatening the survival of the Lake.

The Lake Chad Basin Commission is an intergovernmental cooperation by states around the Lake Chad Basin to enable them pull resources together aimed at the continued, effective and efficient utilization of the Lakes resources. The first initiative to establish this commission was taken by Niger in 1964 when the newly independent African states saw the need to secure and protect the resources of the environment. The connectivity of the Lake among several countries was quickly realized (Odada, Lekan, \& Oguntola, 2005).

As a result, an agreement was reached by the Head of States of Chad, Niger, Nigeria and Cameroon at Fort Lamy (present day N'djamena) that led to the signing of the statute and convention of the Lake Chad Basin Commission (LCBC) on May $22^{\text {nd }} 1964$ (De Young, Antonia, Sinead, \& Sandy, 2012). This was to a great extent an early attempt at cooperation by states around the Lake Chad (Onuha, 2015). Subsequently, in 1968 the Commission signed another agreement to facilitate a joint economic development of the Lake Chad Basin area (De Young, Antonia, Sinead, \& Sandy, 2012). During the period the lakes statute was signed, the lake covered an area of approximately $427,300 \mathrm{~km}^{2}$ referred to as the conventional basin. This size subsequently increased with the admission of new members States like the Central African Republic in 1994 to $966,953 \mathrm{~km}^{2}$, Sudan in July $28^{\text {th }} 2000$, to $103500 \mathrm{~km}^{2}$ and Libya in 2004 (Odada, Lekan, \& Oguntola, 2005), expanding the jurisdiction of the Lake Chad Basin Commission.

\subsection{Aim and Objectives of the Lake Chad Basin Commission}

The aim of the Lake Chad Basin Commission is to coordinate development and promote cooperation among states in the Lake Chad and its drainage basin through the effective management of the lake water resource (Odada, Lekan, \& Oguntola, 2005). This is meant to ensure the effective utilization of the resources by the people around it. Thus, the Commission sought to achieve through the following objectives:

- The regulation and control of the water as well as other resources of the Lake Chad Basin

- The promotion and coordination of natural resource projects and research in the Lake Chad Basin area

- The examination of complaint brought to the Commission 
- $\quad$ The provision for dispute settlement among the member states

- $\quad$ The promotion of regional cooperation among member states (Odada, Lekan, \& Oguntola, 2005).

To further ensure that the aim and objective are tenable, the Commission made sure that member states abstain from projects or activities that will alter the flow and quality of water, influence integrated water resources management as well as limit the downstream access of the lake water to users. Despite these, sovereignty of member states was given cognizance. The Commission recognized the right of the member states over the water resource of the basin within their territorial influence while prohibiting the unilateral exploitation and exploration of the lake resources, especially if this will affect other member states negatively. The Commission also recognized the right of states to plan projects that will develop the lake so long as such project take effect after the Commission is notified and ratifies it. The Commission, therefore, frowns on any activities by member states that will alter the water quality and quantity, as well as the biological characteristics of the lake which included its flora and fauna (De Young, Antonia, Sinead, \& Sandy, 2012).

\section{Impact of the Lake Chad Basin Commission}

\subsection{Socio-Economic Impact of the Lake Chad Basin Commission}

States in the international system tend to cooperate when such cooperation facilitates the achievement of their national interest. When reverse is the case, cooperation become meaningless, unproductive and non-impressive. Cooperation in this sense literarily ceases between the concerned states. The case is not so different for the countries around the Lake Chad Basin area. Apart from the LCBC coming into existence to ensure the continued existence of the Lake Chad Basin, the Commission seeks to ensure the economic viability of the countries around the lake. Countries within the Lake Chad Basin zone are some of the poorest ones in the world, whose citizens lived on less than a Dollar a day. As such, the Commission is meant to improve the economic wellbeing and material welfare of the concerned states. Though Algeria and Libya were excluded from this categorization in the pre- Arab Spring era, the crises (post- Arab Spring) have slide them into some of the most unstable nations in the world. This situation translates directly into economic and material measurements. The economy viability of the countries around the Lake Chad Basin has been affected dysfunctional by certain factors exacerbated by the 1979, 1983, 1989 droughts that ravaged the basin (Lake Chad Basin Commission, 2018). In an effort to mitigate and contain the occurrence of this, the Lake Chad Basin Commission undertook a diagnostic study of the environmental impact; assessment, prevention and pro-activeness of the basin area. This was made possible through the support and assistance of the United Nations Environmental Programme. The positive effect of this exercise was the establishment of the Lake Chad Basin Master Plan completed in 1989. The plan provided "a strategy for the development of an environmental sound management of the basin natural resources in order to ensure sustainable development of the area. In addition to this, the plan identified the main problems hindering the feasibility of an environmentally sound management of the natural resources of the conventional basin.

Furthermore, in trying to address the problems relating to the environment, the LCBC during the $7^{\text {th }}$ Head of States meeting 1994 Abuja, Nigeria adopted a Vision 2025. This Vision's document is committed to seeing that Lake Chad region (which is considered as common heritage) and other wetlands by the year 2025 were preserved to ensure the economic security of the freshwater ecosystem, biodiversity and aquatic resources of the basin. The use of which should be equitable to serve the needs of the population of the basin, thereby reducing the poverty level.

The Lake Chad Basin vision, as stated in the Vision Document 2025 is:

The Lake Chad Region would like to see by the year 2025 the Lake Chad-common heritage - and other wetlands maintained at sustainable levels to ensure the economic security of the freshwater ecosystem resources, sustained biodiversity and aquatic resources of the basin, the use of which should be equitable to serve the needs of the population of the basin thereby reducing the poverty level.

The two principal objectives of the Lake Chad Vision, also consistent with the Africa Water Vision, are:

- A Lake Chad Region where the regional and national authorities accept responsibilities for freshwater, ecosystem and biodiversity conservation and judicious integrated river basin management to achieve sustainable development.

- A Lake Chad Region where every Member State has equitable access to safe and adequate water resources to meet its needs and rights and maintain its freshwater, ecosystem and biodiversity resources (Lake Chad Basin Conmission, 2008).

To achieve this, the Lake Chad Basin Commission has been able to solicit assistance from World Bank through 
their finance of Global Environment Facility (GEF) programs. This has helped in the reversal of land and water degradation trends in the Lake Chad ecosystem. The project is aimed at ensuring the development and continued existence of the lake by increasing the water level and the quantity of fish, water available for agriculture all year round and invariably create job for the local population of states around the lake. The GEF project was specifically aimed at overcoming barriers to the concerted management of the basin through well-orchestrated and enhanced collaboration and capacity building among riparian states and stakeholders. The program was to see to the completion of a Trans -boundary diagnostic analysis, preparation of a Strategic Action Program (SAP) and execution of six pilot projects in the five LCBC countries. The program was co-sponsored by the LCBC, GEF and UNDP.

In addition, the Lake Chad Basin Commission was able to create a Basin Committee for Strategic Planning (BCSP) to assist in the creation of the local initiatives. A Technical Steering Committee made up of member states representatives, created to facilitate the achievement of the GEF project. The BCSP comprised senior country officials, across key ministries such as environment, agriculture, and finance, to increase the likelihood, where necessary, policy and administrative changes and funding priorities to prevent replication of the most promising locally driven enterprises to be implemented and driven by enterprise that operate locally (Lake Chad Basin Commission).

\subsection{Political Impact of the Lake Chad Basin Commission}

The LCBC had a significant political impact on the relations among states around the Lake Chad by facilitating cooperation rather than conflict that may result from individual development of the lake. As the Commission was able to bring together states with different but similar historical background brotherhood, cooperation, togetherness were fostered and ensured. For example, Nigeria was colonized by the British and an English-speaking country while the other states like Niger, Chad, were colonized by France and are French speaking countries, Cameroon is both an English and French speaking country. The member countries are not only different with regards to history but also belonging to different regional organization the ECOWAS (Economic Community of West African States) and ECCAS (Economic Community of Central African States) (Galeazzi, Tarila, Ebiede, \& Sophi, 2015). However, these did not hamper the states coming together, through cooperation to agree on means to ensure the continued existence of the Lake Chad. According to Unoha, the LCBC was one of the first attempts by riparian states to ensure the promotion and regulation of the water as well as the resources of the Lake Chad (Onuha, 2015). This therefore, marked the beginning of cooperation that propelled the effective utilization of the Lake Chad water and resources. In the same vein, cooperation strengthened the safety and security of these states' inhabitants in their border towns around the Lake Chad Basin. The Multinational Joint Task Force by three Head of States of the Lake Chad Basin Commission was initiated in this line of cooperation to help checkmate the maligning security challenges and threats. These Head of States included Chad, Niger and Nigeria, who set up the Task Force to end banditry activities and ensure the free movement of their people and goods across borders around the Lake Chad Basin. Cameroon subsequently joined the MNJTF to secure its territories against criminal banditry, kidnapping, pillaging and insurgency.

The Lake Chad Basin Commission through its objective which include the promotion and coordination of natural resource projects and research in the Lake Chad Basin area ensured that member countries participate in projects aimed at ensuring the continued existence of the lake. This therefore, promoted and fostered regional oneness and cooperation. By promoting regional cooperation among member states the Lake Chad Basin Commission made it easy for the citizens of member states to cut across boundary to sell their products in market across boundaries. The importance can be seen in the establishment of the nodal fish market in Nigeria bringing farmers, fishermen and buyers from within and across the Lake Chad Basin countries (Odada, Lekan, \& Oguntola, 2005).

The Lake Chad Basin Commission was established to provide an avenue for states to channel complains with regards to the Lake Chad and its resources without recourse to conflict and crises. In this vein, conflict resulting from the use of resources are easily channeled and addressed. The significance of this platform will not be lost if its known as it is that lack of rainfall, climate malfunction and the increase in population have forced people continually to move further inward to access the resources. The fear of invincible crossing into boundary line of other countries is thus, eliminated because of common understanding as encapsulated in the Commission's clauses. However, it should be stated that free access has created negative and dysfunctional consequences among member states. Often there are local and degraded clashes and demented crises among users of the facilities of the Lake Chad Basin by various nationals. Again, high level of migration by member states countries citizen who arguably carry out some unacceptable criminal acts in other countries are well known. A case in point and recent is the decade long issue of insecurity that has engulfed the states around the Lake Chad Basin; the Boko Haram Menace. There have been series of facts to show that most of the elements of this group utilize 
the easy access to and from member countries to perpetrate their act of terror. This by engaging in hit and run tactics that takes them into the nearest countries to Nigeria. The easy access has also provided them the avenue to bring in weapons to perpetrate their acts of terror.

\subsection{Challenges of the Lake Chad Basin Commission}

Despite the objectives of the Lake Chad Basin Commission aimed at ensuring the continued existence and development of the Lake Chad Basin, its resources and those of the citizens around it, the Commission faces series of challenges forestalling the realization of these objectives. These include:

\subsection{Political Will of Member States}

Although the Lake Chad Basin Commission brought together states with similar historical experience of colonization and struggle for independence, these states still lack the political will to ensure that the objectives of the Commission come into fruition. Change of political leadership, lack of common and equal stakes and stereotyping of the erstwhile colonial masters have all combined to prevent smooth political operation of the intent and objectives of the Commission. Countries like Niger, Chad and Cameroon are still tied to the apron spring of their colonial masters. It is well known that France still holds high political and economic stakes in her erstwhile colonized states of Africa. This has led to the absence of a sustainable development and wise use of the resources of the lake and agreement to manage it. Also, a source puts it: 'the fact that the lake has been shrinking has made countries around the lake to lose interest' (Odada, Lekan, \& Oguntola, 2005). This affecting the effective trans- boundary management of water, prevention of the continued degradation and loss of water by the Lake Chad Basin to ensure the socio-economic benefits of its resources. This was also seen to be the reason behind the lake of commitment to International Multilateral Environmental Agreements (MEAs) (Adeniran \& Ndimele, 2018).

\subsection{Inadequate Funding}

For any organization to effectively carry out its objectives, there is need for the provision and availability of funds to ensure that projects objectives are feasible. To this, Lake Chad Basin Commission in 1990 reform downsized its financial requirement from initial US $\$ 1,000,000$, so each member state could contribute without any hindrance. The reform also determined the formula for contribution by each state. Nigeria as a result is expected to contribute 52\%, Chad 11\%, Cameroon 20\%, Niger 7\% and CAR 4\%. From the overs all total, 50\% is to be used for the smooth running of the Commission and $40 \%$ for developmental projects (Odada, Lekan, \& Oguntola, 2005). Despite the downsizing, the LCBC member states have been unable to meet up with the payment of their annual financial contributions. As put by the LCBC Executive Secretary Alhaji Sanusi Abdullahi, the lack of payment of the member states resulted in the inability of the Commission to achieve up to $70 \%$ of its projects. Only Nigeria, has been able to meet up with its contribution (News Agency of Nigeria, 2018). Making the organization and its members to lose the respect of both their technical and financial partners, thereby leaving most of its projects uncompleted.

\subsection{Unavailable Trans-border Water Management Mechanism}

Lack of effective trans-boundary water management to prevent the continued loss of water by the Lake Chad Basin to ensure that member states achieve the desired socio-economic benefits is a critical minus to the smooth operation of the Commissions' agreement (ICPDR - International Commission for the Protection of the Danube Rive and Vienna international center room, 2012). Member countries of the LCBC have resorted to individual management of the lake resources at the expense of other members. This is against the principle of the Commission. Most of the member states continue to engage in damming the lake water within their jurisdiction, using it for other irrigational activities, that draws more water from the lake than what it receives from rainfall. Lack of water usage discipline and responsibility is key to the depletion of the water system of the Lake. It is estimated that this irresponsible usage has led to the shrinking of the Lake water four times (ICPDR International Commission for the Protection of the Danube Rive and Vienna international center room, 2012) its actual size. The Director General of Mother of Earth Foundation puts it succinctly;

Why is Lake Chad shrinking? One is global warming and number two is inefficient management of the watershed and this has caused displacement of both pastoralists and fisher folks who depend on the water. Some irrigation systems that have been drawing water their rate of taking water is more than the rate of recharge from rain so, this kind of thing needs to be managed properly. So, the countries in Lake Chad Basin Commission needs to sit down together and look at ways of enforcing best practices to maintain and protect the water treasures that we have. 


\subsection{Organizational Structure}

Another challenge of the Lake Chad Basin Commission is the lack of proper organizational setting and official mechanism to effectively carry out its objectives. While it has been able to carry out some organizational reforms in 2008 and 2011, the Commission is still unable to achieve the desired outcome. A study of the structure showed that there are more management staff than field experts. These managerial staffs consist of more directors who are highly paid. This, makes it very cumbersome and expensive for the Commission to run effectively. In addition, managerial positions are often filled with unqualified personnel (Hutten \& Keil, 2013).

\subsection{Information Disconnectedness}

Information flow sluggishness between different departments as well as member states countries is one of the challenges that the LCBC is facing. This challenge is a result of the structure of the Commission, having more directors than field staffs. Information flow from the departments in the Commission seemed to be disturbed as these directors do not organize regular meetings to share information and implement annual strategic action plan, especially between departments that represents the different member states. This therefore, makes it difficult to prioritize projects to be implemented in the different states that will translate into the LCBC owns rather than member states own. This lack of information sharing is also seen in the relationship between the focal points and the LCBC.

\subsection{Visibility to the Outside World}

Another challenge of the LCBC is that of visibility. The fight against Boko Haram terrorist since 2009 has underscore the importance of the Organization. LCBC has remained before then a blurred one whose activities were considered cliché and unimpressive. Its contacts with the outside world were weak and uncoordinated. For this reason, among others, the global Cooperative Organizations are delinked with the Commission. It is simply inconceivable that the Commission lack effective virtual and material addresses for the global world to view and access.

\subsection{Cultural and Language Differences}

Another bedeviling factor of LCBC is the cultural and language differences. Though cultural and linguistic differences are supposed to be strong upholding feature of any serious Organization, but that is where diversity is effectively managed and productively manipulated. In the case of the Commission, diversity has become a burden as Francophone and Anglophone dichotomy has often than not polarized decisions, project enunciation, policy definition and enforcement and operational activities and cohesion. Rather than allowing the rules and regulations of the Commission to guide and direct activities, LCBC directors often representing member states followed the dictates of their countries and personal whims (Hutten \& Keil, 2013).

\subsection{Violent Banditry Activities and Terrorism}

Another challenge the LCBC is facing is the conflict-ridden nature of the basin area. Cultural violence, religious insurgency and primitive terrorism have become the lots of the member countries. Nigeria, Cameroon and Niger are faced with Boko Haram menace, Mali with ethnic and racial conflagration while Algeria and Libya have almost become failed states. The region has become synonymous with crises. In this kind of situation, political and material stabilities are difficult and rare ingredients. The effect of all these is lack of cultural development and stability that evolved through history and systematic growth. In the same vein, crises scared research prognosis and interrogation. Thus, the zone has no adequate and sufficiently accurate information to spur up developmental interest and support for LCBC projects (Milner, 1992).

\section{Conclusion}

In conclusion, the LCBC is an intergovernmental organization bringing together states around the Lake Chad Basin to enjoy maximum benefit from the lake. The Lake Chad Basin is an important lake, with over 50 million people depending directly on it and close to 50million leaving around it that depend on its water and resources. This population is within the border town of the LCBC member states around the lake. However, lack of political power among the members of the Commission, inadequate funding, existence of trans- border crimes, banditry and terrorism and lack of coordinated program and developmental blue print have combined to frustrate the realization of what appear apparently as lofty objectives. In order to realize the noble idea behind the creation of the LCBC, there is the urgent need to inject funds into the coffer of the Commission, make and enforce decision actions cooperatively to tackle banditry and terrorist activities. This is to make it easy to seek the cooperation of Donor Agencies, International Organizations and communities. 


\section{References}

Primary Sources

\begin{tabular}{|c|c|c|c|c|c|}
\hline 1 & Major Y. A. & $40+$ & Serving in the MNJTF, (from 2017) & Borno State & $12-01-2019$ \\
\hline 2. & Brigadier Gen. Ali Keffi & $50+$ & $\begin{array}{c}\text { Soldier (served in MNJTF } \\
\text { 2012-2016) }\end{array}$ & $\begin{array}{c}\text { Abuja, Defence } \\
\text { HQ }\end{array}$ & $27-9-2017$ \\
\hline 3. & $\begin{array}{l}\text { Brigadier Gen. T. A. } \\
\text { Lagbaja }\end{array}$ & $50+$ & Soldier (served in MNJTF 2012-2016 & $\begin{array}{c}\text { Abuja, Defence } \\
\text { HQ }\end{array}$ & $27-9-2017$ \\
\hline 4. & Captain Chukwuemeka, & $30+$ & $\begin{array}{c}\text { Soldier (served in MNJTF, } \\
\text { 2012-2015) }\end{array}$ & Kaduna & 20-03-2018 \\
\hline 5. & $\begin{array}{l}\text { Captain S. O. Olaniyi } \\
\text { (NRN) }\end{array}$ & $30+$ & $\begin{array}{l}\text { Soldier (served in the North East } \\
\text { 2012-2016) }\end{array}$ & Kaduna & $20-03-2018$ \\
\hline
\end{tabular}

Living Waters Programme. (n. d.). Managing rivers wisely: Lake Chad. (p. 4).

Adeniran, A., \& Ndimele, P. (2018). Fostering Trans-boundary and International Cooperation in The Lake Chad Basin. The International Conference on Lake Chad Basin (p. 3). Abuja Nigeria: Lake Chad Basin.

Ahmed, O. A. (2008). Maintenance of Security and Good Governance in Kaduna State:An Assessment of the Period 1999 - 2005.). In C. e. In Ubah, Studies on Kaduna State (pp. 29-52). Kaduna Nigeria: Nigerian Defence Academy Press.

Ake, C. (1991). Re Thinking Africa. Africa Journal of Democracy Winter, 2(1), 209-221.

Bienen, H. (1983). The State and Ethnicity: Integrative Formula. In V. O. (Eds.), State Versus Ethnic Claims: African Policy Dilema (pp. 100-126). Colorado: Western Press. https://doi.org/10.4324/9780429307485-6

Binder, L. (1964). National Integration and Plural Development. American Political Review. https://doi.org/10.2307/1953137

De Young, C., Antonia, H., Sinead, S., \& Sandy, D. ( 2012 ). Climate Change Implications for Fishing Communities in the Lake Chad Basin: What Have We Learned and What Can We Do Better? FAO Fisheries and Aquaculture Proceedings, NO2 (p. 32). Rome: Food and Agriculture Organization of the United Nation.

Federal Ministry for Economic Cooperation and Development. (2015). Africa Supraregional: Adaptation to Climate Change in the Lake Chad Basin. Bon, Germany: Deutsche Gesellschaft fur Internationale Zusammenarbeit (GIZ) GmbH.

Fortman, M., \& Oguntola, J. (2016). Lake Chad Basin . London: UNEP: GIWA Regional Assessment Offfice.

Fortune Afafrica. (2017). List of lake in Africa fortune of Africa. Retrieved from http://fortuneofafrica.com/lakes-africa.

Galeazzi, G., Tarila, A. M., Ebiede, M., \& Sophi, D. (2015). Understanding the Lake Chad Basin Commission $(\mathrm{CBC}$ ): Water and Security at Inter-Regional Crossroads. London: European Centre for Development Policy Management.

Hansel, K. (2017). The Rise and Fall of Africa's Great Lake: Scientists Try to Understand the Fluctuations of The Lake Chad. Canada: Earth Observatory: Earthobservatory.Nasa.Org.

Hutten, K., \& Keil, M. (2013). Assessment of The CBLT Reform and the Challenges of Adaptation to an Efficient and Effective Transboundary Secretariat. Vienna.

ICPDR - International Commission for the Protection of the Danube Rive and Vienna international center room. ( 2012). Bringing the experience of Africa's Lake Chad Commission to the banks of the Danube. Austria: Danube watch 2.

Imobighe, T. A. (1990). Doctrines for threats to Internal Security. In A. E. (Eds), Nigerian Defence Policy: Issues and Problems (pp. 46-61). Lagos Nigeria: Malthouse Press Ltd.

Lake Chad Basin Commission. (2018). Projects. Retrieved from http://www.cblt.org/en/projects. (Accessed 5th April 2018).

Lake Chad Basin Commission. (n. d.). The Lake Chad Development and Climate Resilience Action Plan. World 
Bank Group.

Lake Chad Basin Conmission. (2008). Reversal of Land and Water Degradation Trend in the Lake Chad Basin Ecosystem, Strategic Action Programme for the Lake Chad Basin. Chad: LCBC Member States of Cameroon, Central African Republic, Chad, Niger, and Nigeria, Final SAP.

Mazrui, A. (1972). Cultural Engineering \& Nation Building in East Africa. Evanston: North Western University.

Milner, H. ( 1992). International Theories of Cooperation Among Nation: Strength and Weaknesses in World Politics. Cambridge: Cambridge University Press. https://doi.org/10.2307/2010546

News Agency of Nigeria. (2018, February 23). Insurgency, climate change challenges to Lake Chad Basin development. The Guardian Nigeria Newspaper, p. 6.

Odada, E. O., Lekan, O., \& Oguntola, J. A. (2005). Lake Chad: Experience and Lessons Learned Brief. Environment Committee (ILEC) Foundation.

Ogbozor, E. ( 2016). Resilience to Violent Extremism: The Rural Livelihood Coping Strategies in the Lake Chad Basin. 12th Annual HiCN Workshop on Violent Conflict, Resilience and Agriculture, from Emergency to Developmen (p. 10). Rome: HouseHold in Conflict Network (HiCN).

Okene, A. A. (2011). National security, good governence and integration in Nigeria since 1999: A discourse. Asian Social Science, 7(10), 166-176. https://doi.org/10.5539/ass.v7n10p166

Onuha, F. C. (2015). Climate Change, Population Surge and Resource Overuse in the Lake Chad Area: Implication for The Human Security in The North East Zone of Nigerian. In D. A.-A. (Eds.), Climate Change and Natural Resource Conflict in Africa, Pretoria (p. 23). Abuja: Institute of Security Studies.

Paulo, S. (2014). International Cooperation and Development: A conceptual overview. Germany: German Development Institute (DIE). https://doi.org/10.2139/ssrn.2430206

Tar, B. B. (2020). Emerging Architecture for Regional Secuirty Complex in the Lake Chad Basin: The Mulitinational Joint Task Force in Perspective. In U. A. Bala, New Architecture of Regional Security in Africa: Perspectives on Counter-Terrorism and counter-Insurgency in the Lake Chad Basin (pp. 141-166). United Kingdom: lexington Books.

Umara, I. (2020). Lake Chad Basin Commission: Emerging Framework for Security Regionalization in the Lake Chad Basin. In U. A. Bala, New Architecture of regional Security in Africa: Perspectives on Counter-Terrorism and Counter-Insurgency in the lake Chad Basin (pp. 127-140). United Kingdom: Lexington Books.

World Food Program. (2016). Socio-Economic Analysis of the Lake Chad Basin, With Focus on Regional Environmental Factors, Armed Conflicts, Gender and Food Security Issues. Lake Chad Basin Desk Review, 4.

\section{Copyrights}

Copyright for this article is retained by the author(s), with first publication rights granted to the journal.

This is an open-access article distributed under the terms and conditions of the Creative Commons Attribution license (http://creativecommons.org/licenses/by/4.0/). 